\title{
The Current Survey of Indigenous Arbuscular Mycorrhizal Fungi of Wheat (Triticum aestivum) in Benghazi's Coastal Plain
}

\author{
Marei Abdullah \\ Plant Production Department, \\ Faculty of Agriculture/ Suluq, \\ University of Benghazi \\ marei.abdullah@uob.edu.ly
}

https://doi.org/10.36602/jmuas.2019.v01.01.23

\begin{abstract}
Rhizospheres of crop plants are complexes of chemical and microbial interactions. Of importance, arbuscular mycorrhizal fungi (AMF) are beneficial microorgansims associated with roughly eighty-percent of terrestrial land plants. In this mutualistic symbiosis, the fungus receives photosynthetic product (sugar) fixed from its host by photosynthesis. In return, the host plant gains a plethora of benefits from the fungus such as enhanced nutrient uptakes, protection against both biotic (soil-borne root pathogens, insect attack) and abiotic (drought, heavy metal pollution, and soil salinity) stresses. Taxonomically, AMF belong to a new erected phylum called Glomeromycota. The field study was conducted in a farm owned and supervised by The Great Man-Made Project in February 2019. The present study was performed to determine the presence or the absence of AMF in a field cultivated with wheat crops (Triticum aestivum, L.) during the vegetative stage, and also to investigate soil physiochemical properties effect on AMF colonization. Results showed that colonization of wheat plant roots were significantly low. The result clearly implies that highinput fertilizers viz., phosphorus fertilization, and agricultural practices such as intensive tillage drastically reduced AMF colonization.
\end{abstract}

Keywords: Arbuscular mycorrhizae-rhizosphere-microbial interaction-wheat.

\section{Introduction}

Wheat is one of the most important cereal and staple crops worldwide, and domestication of wheat led to the development of agriculture-based human societies. Wheat is a central crop in the Libyan diet with a variety of usages, for instance, its flour used for making bread, pasta. In addition, wheat straw is used for feeding livestock as a complementary nutrition with barley grains. Wheat is classified in the genus Triticum belongs to the botanical Family Gramineae; the number of species in the genus varies based on the classification system, but modern classification places the number of species at about 30 (Goncharov, 2011). Statistically speaking, wheat production in Libya valued 104000 tons in 2008, and will be projected to 165712 tons in 2016 (FAO). As the numbers imply, the production of wheat is significantly is low. Different factors contribute to this shortage 
including: effect of edaphic factors such as soil salinization and low soil fertility; and environmental factors (e.g., wind erosion, and drought). Therefore, most of the country's demand for wheat is imported from Europe, and recently Eastern Europe.

Arbuscular mycorrhizal fungi (AMF) are omnipresent soil inhabitants that are able to form symbiotic associations with root systems of most plant species. In 2001, Schüßler et al moved AM fungi from Phylum Zygomycota to a newly described Phylum Glomeromycota based on small subunit rRNA gene sequences. Colonization of plant roots with AMF improves the host acquisition status of inaccessible minerals (e.g., phosphorus) that otherwise unavailable. Fungal hyphae extend several centimeters, and explore the soil particles efficiently to reach $\mathrm{P}$ that beyond root hairs range and translocate it to the host for consumption (Smith and Read, 2008). It has been well documented that mycorrhization protects plant host from important fungal soil-borne pathogens such as Verticilum, Fusarium, and Phytophathora (Aguilar, and Barea, 1997) and pests alike through up-regulations of gene expressions such as jasmonic acid (JA) and salicylic acid (SA) that are quintessential in activating Systematic Acquired Resistance (SAR) (Gutjahr and Paszkowski, 2009; Fu, and Dong, 2013).

The aims of this current study are to determine the presence or the absence of arbuscular mycorrhizae fungi on wheat roots, and to examine the effect of physio-chemical soil properties on AMF colonization during the vegetative stage.

\section{Material and methods}

\section{Description of study site:}

The current survey was conducted in Benghazi's coastal plain, January 2019(GPS coordinates: $31.850265,20.242023$ ). The study area of interest is a cultivated wheat field managed by The Great Man-Made River Project. The climate is relatively semi-arid with an unprecedented annual precipitation exceeding $300 \mathrm{~mm}$. The mean annual temperature in the region was $28 \mathrm{C}^{\circ}$. The field is well irrigated, and received sufficient amount of fertilizers: both macronutrients (N, P, K 50:0: 50) and micronutrients (YaraVita Pholate Burgundy, the UK).

\section{Rhizospheric soil sampling:}

Rhizospheric soil with wheat roots was collected using a soil auger from the $10-15 \mathrm{~cm}$ soil depth. Soil samples were air dried at room temperature for 24 hours. The samples then were grounded and passed through a 2-mm mesh sieve. Soil textural classes were classified according to the United States Department of Agriculture (USDA) triangle system (Soil Survey Staff, 1951), and soil chemical properties such as organic matter $(\mathrm{OM}), \mathrm{pH}$, and available phosphorus contents were determined by standard laboratory 
protocol. All soil analyses were performed at the laboratory of The Great Man-Made River Project, Benghazi, Libya.

\section{AMF wheat root colonization assessment:}

Twenty wheat plants were selected randomly in the study site. Roots were excised, and rinsed several times with tap water to remove soil particles. Roots then were boiled in $10 \% \mathrm{KOH}$ for 20 mints to clear roots. Roots were immersed in a 5\% ink-vinegar solution for 5 mints. The ink-vinegar solution was used instead of traditional Trypan blue solution due to its carcigenoic effect, and high-cost price (Vierheilig et al. 1998). Roots then were destained in pure household vinegar for 1 hour. Finally, roots were cut into small pieces, and kept in beaker- contained tap water until mounted on microscopic slide $(25.4 \times 76.2 \times$ $1 \mathrm{~mm})$ (Hamilton) and covered with glass slip $(24 \times 60 \mathrm{~mm})$ for observing AMF structures such as vesicles, hyphae, and arbuscules.

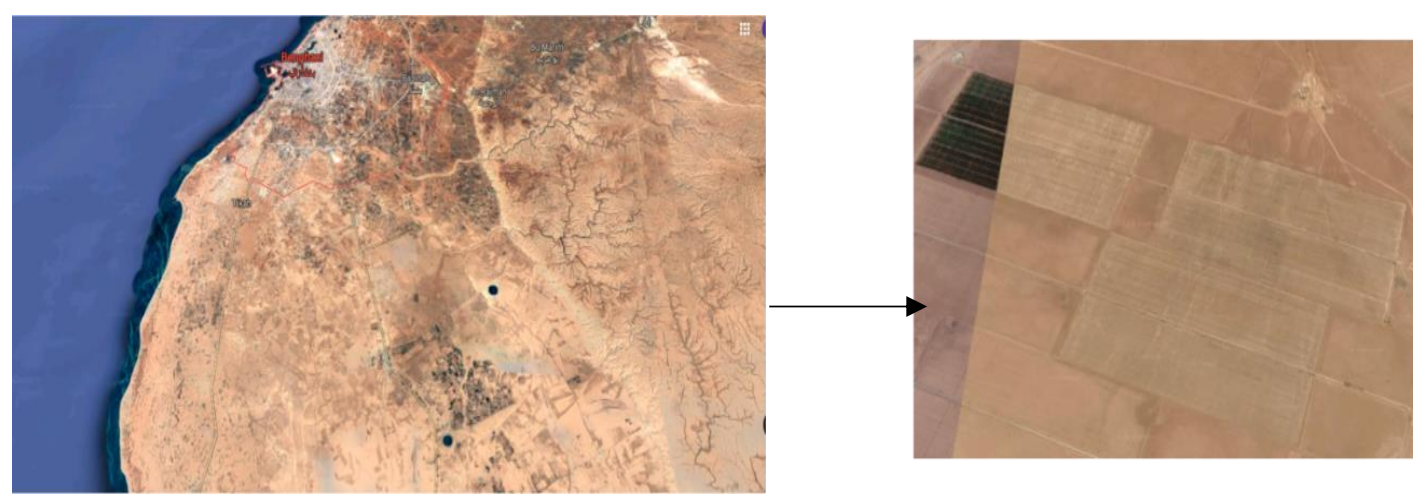

Figure 1: Geographic study location

\section{Results and discussion}

\section{The effect of Soil physio-chemical properties on AMF colonization:}

Soil texture was silty-clay (35\%, and $43 \%$ respectively) as shown in Table 1 below. Table 1 also shows that both total nitrogen and phosphorus contents were significantly low compared to potassium. It is well documented that high soil phosphorus significantly reduces AMF colonization of its host plant (Breuillin et al., 2010; Kobae et al., 2016). In our study, AMF colonization was low and that could be attributed to agriculture practices, for example, intensive tillage. In addition, seasonal variation might cause this decline of AMF colonization. Furthermore, lower colonization in this survey can be attributed to long fallows, also known as long fallow disorder (Thompson, 1987). The soil $\mathrm{pH}$ is generally alkaline as shown in Table 1 . Soil $\mathrm{pH}$ dramatically affects both AMF spore density and germination. Isobe et al., 2007 reported that AMF spore numbers were higher 
when $\mathrm{pH}$ ranged (6 to 8 ), however, some exceptions can be found depending on the specific AMF strains.

Note: WHC, water holding capacity; HC, hydraulic conductivity; EC, electrical conductivity; CEC, cation exchange capacity; OM, organic matter; $\mathrm{N}$, total nitrogen; $\mathrm{P}$, available phosphorus; $\mathrm{K}$, available potassium.

In this study, arbuscules and external AMF hyphae were observed in most of tested wheat roots as illustrated in Fig 2.

Arbucules are considered to be the main exchange site of nutrients between the plant host and its mycobiont. It is noteworthy in this current study that AMF vesicles are absent or still not formed in all tested roots and that might be due to early colonization events, i.e., not giving the fungus the required time for developing vesicles.

Table 1. Soil physical and chemical proprieties

\begin{tabular}{cc}
\hline Parameter & Value \\
\hline Soil texture & Silty clay \\
Sand (\%) & 22 \\
Silt (\%) & 43 \\
Clay (\%) & 35 \\
WHC $(\%)$ & 35.52 \\
HC $\left(\mathrm{cm} \mathrm{h}^{-1}\right)$ & 2.40 \\
EC $\left(\mathrm{dS} / \mathrm{m}^{-1}\right)$ & 0.5 \\
CEC $\left(\mathrm{Cmole} \mathrm{kg} \mathrm{kg}^{-1}\right)$ & 25 \\
$\mathrm{pH}$ & 8.2 \\
$\mathrm{OM}(\%)$ & 1.24 \\
$\mathrm{~N}(\%)$ & 0.1 \\
$\mathrm{P}(\mathrm{ppm})$ & 11 \\
$\mathrm{~K}(\mathrm{ppm})$ & 995 \\
\hline
\end{tabular}

\section{Summary}

Our current survey demonstrates that wheat association with arbuscular mycorrhizal fungi (AMF) is comparatively low. Lower AMF colonization is quite possibly caused by several factors such as intensive tillage practice, seasonal variation, and long fallow disorder. Another survey should be conducted at the mature stage or prior to harvesting to allow wheat plants an adequate time for developing better AMF colonization. Monitoring AMF activities in our soils would definitely enhance domestic wheat production in terms of both quality and quantity. 


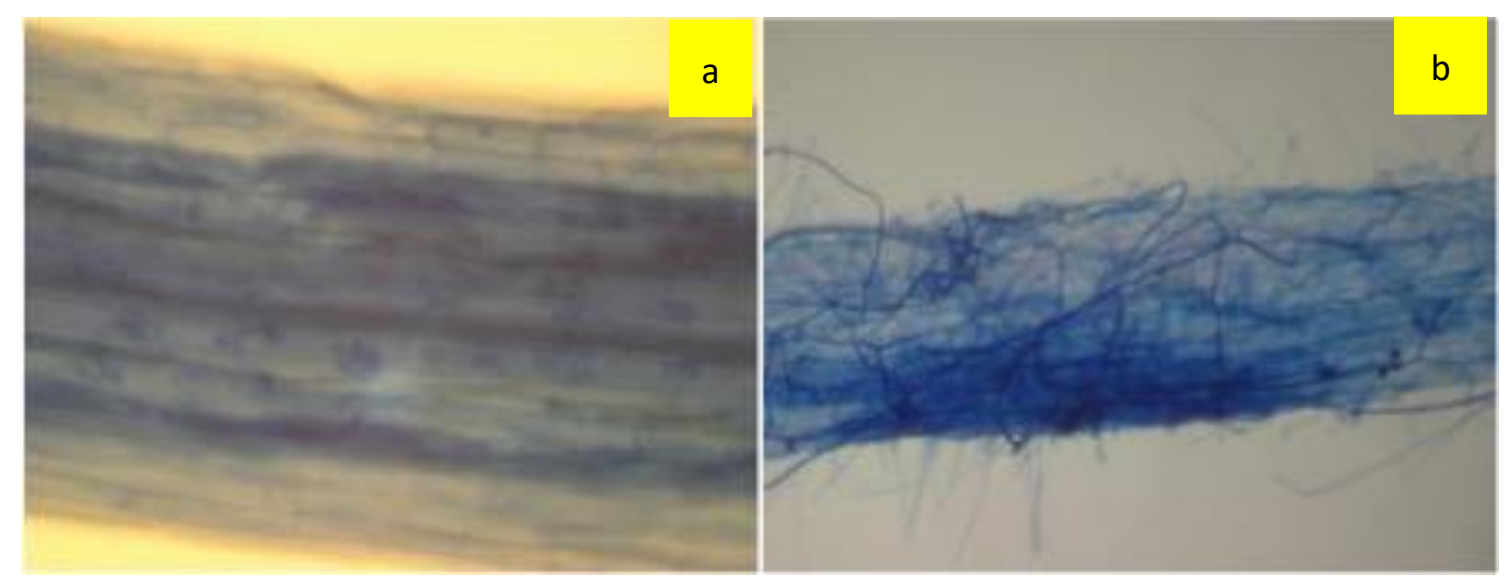

Figure 2: Wheat roots colonized by AMF. Arbuscules (a), and (b) external AMF hyphae.

\section{Acknowledgments}

The author is truly thankful to "The Great River Project Water Utility" for soil analysis, and classification.

\section{References}

Aguilar, C. and Barea, J.M. 1997. Arbuscular mycorrhizas and biological control of soilborne plant pathogens- an overview of the mechanisms involved. Mycorrhiza 6: 457-464.

Breuillin, F. Schramm, J. Hajirezaei, M. Ahkami, A. Favre, P. Druege, U. Hause, B. Bucher, M. Kretzschmar, T. Bossolini, E. Kuhlemeier, C. Martinoia, E. Franken, P. Scholz, U. Reinhardt, D. 2010. Phosphate systemically inhibits development of arbuscular mycorrhiza in Petunia hybrida and represses genes involved in mycorrhizal functioning. Plant J 64: 1002-101.

Katsunori Isobe, Emi Aizawa, Yosuke Iguchi, and Ryuichi Ishii. 2007. Distribution of arbuscular mycorrhizal fungi in upland field soil of Japan 1. relationship between spore density and the soil environmental Factor. Plant Production Science, 10:1, 122-128.

FAOSTAT. (2016). FAO Statistical Database, Libya.

Fu, Z. and Dong, X. 2013. Systemic Acquired Resistance: Turning Local Infection into Global Defense. Annual Review of Plant Biology, 64 (1), pp.839-863.

Goncharov, N. P. 2011. Genus Triticum L. taxonomy: the present and the future. Plant Systematics and Evolution 295: 1-11. 
Gutjahr, C. and Paszkowski, U. 2009. Weights in the Balance: Jasmonic Acid and Salicylic Acid Signaling in Root-Biotroph Interactions. Molecular Plant-Microbe Interactions, 22(7), pp.763-772.

Horst Vierheilig, Andrew Coughlan, Urs Wyss,and Yves Piche. 1998. Ink and Vinegar, a Simple Staining Technique for Arbuscular-Mycorrhizal Fungi. American Society for Microbiology. 64:4.

Kobae, Y., Ohmori, Y., Saito, C., Yano, K., Ohtomo, R., \& Fujiwara, T. 2016. Phosphate Treatment Strongly Inhibits New Arbuscule Development But Not the Maintenance of Arbuscule in Mycorrhizal Rice Roots. Plant physiology, 171(1), 566-579.

Schüßler A, Schwarzott D, and Walker C. 2001. A new fungal phylum, the Glomeromycota: phylogeny and evolution. Mycological Research 105: 1413-1421.

Smith, S. E and Read, D. J. 2008. Mycorrhizal Symbiosis. $3^{\text {rd }}$ ed. Academic Press, London. Soil Sci. 84, 355-363.

Soil Survey Staff. 1951. Soil Survey Manual. USAD handbook, No. 18. USDA, Washington, DC.

Thompson JP. 1987. Decline of vesicular-arbuscular mycorrhizae in long fallow disorder of field crops and its expression in phosphorus deficiency of sunflower. Australian Journal of Agricultural Research 38: 847-67. 


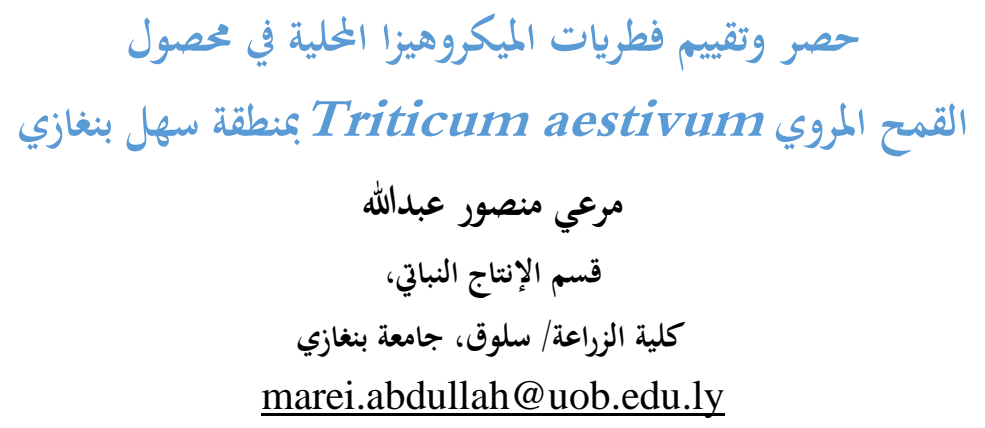

https://doi.org/10.36602/jmuas.2019.v01.01.23

الملخص

تعد منطقة الرايزوسفير الخاصة بالمحاصيل الحقلية منطقة معقدة لاحتوائها علي عديد من التفاعلات الكيمائية والحيوية بين الكائنات الحية المختلفة ذات الأهمية، فطريات الميكروهيزا هي فطريات جذرية تكون علاقة تكافلية مع حوالي ثمانين بالمائة من النباتات الأرضية، في هذه العلاقة يتحصل الفطر من النبات العائل على منتج السكر المثبت خلال عملية البناء الضوئي، في المقابل يستفيد العائل النباتي من الفطر في زيادة تحسين امتصاص العناصر الغذائية الخاصة الغير المتاحة، والوقاية من تأثير العوامل الحية (أمراض التربة المتسببة عن الفطريات، والإصابة الحشرية) والعوامل الغير الحية أو البيئية (الجفاف، والتلوث بالعناصر الثقيلة، وملوحة التربة)، من الناحية التقسيمية، تنتمي فطريات الميكروهيزا إلى شعبة حديثة هي الجلومروميكوتا، أجريت هذه الدراسة الحقلية في مشروع النهر الصناعي في شهر فبراير 2019، تحف هذه الدراسة الحالية إلى تقييم مدى وجود أو غياب هذه الفطريات في حقول القمح المروية خلال مرحلة النمو الخضري وأيضا إلى تأثير عوامل التربة الفيزيائية والكيمائية على استعمار الفطريات لجذور القمح، النتائج المتحصل عليها أظهرت أن نسبة استعمار الميكروهيزا لجذور القمح كانت ضعيفة، ويرجع السبب إلى الأسمدة المضافة خاصة المحتوية علي عنصر الفسفور المثبط لنمو هذه الفطريات والعمليات الزراعية مثل الحرث العميق للتربة. 